\title{
Pelatihan Kerajinan Eceng Gondok untuk Menumbuhkan Wirausaha Baru di Kecamatan Banyubiru
}

\author{
Ning Setiati, Amin Retnoningsih, Nur Kusuma Dewi \\ Universitas Negeri Semarang \\ ningsetiati@mail.unnes.ac.id
}

Key word:

Rawapening;

handicraft;

Eichornia

crassipes;

marketing

Kata Kunci

Rawapening;

kerajinan

tangan; eceng

gondok;

pemasaran

\section{Abstract}

The aim of community service carried out by KKN students in Kebondowo Village and Demakan Village, Banyubiru District, located around Rawapening, is 1) to provide easy use of water hyacinth; 2) provide practical skills in the use of social media for marketing; 3) reduce the skill level of the skill briefing. The methods used in completing the objectives are 1) training in material assistance, 2) practical assistance to finishing, 3) business analysis and marketing. The results of these mentoring activities are: 1) increased workforce capable of making handicrafts from water hyacinth in a number of forms; 2) product marketing at the Rawa Pening lake attraction, Bukit Cinta and provincial level bazaar and expo events; also 3) helps businesses make social media also join in and fill content with product images. Overall, the outputs from this service were obtained and strived to be owned, strived to be independent, production, and consultation with UNNES.

\section{Abstrak}

Tujuan pengabdian masyarakat yang dilaksanakan oleh mahasiswa KKN di Desa Kebondowo dan Desa Demakan Kecamatan Banyubiru yang berlokasi di sekitar Rawapening adalah 1) memberikan keterampilan pemanfaatan eceng gondok; 2) memberikan keterampilan praktis dalam penggunaan social media untuk pemasaran; 3) mengurangi tingkat pengangguran dari pembekalan keterampilan tersebut. Metode yang digunakan dalam pencapaian tujuan adalah 1) pelatihan dalam bentuk pemberian materi secara teori, 2) pendampingan praktek sampai finishing, 3) analisa usaha dan pemasaran. Hasil dari kegiatan pendampingan ini adalah: 1) bertambahnya tenaga terampil yang mampu membuat kerajinan dari eceng gondok dalam berapa bentuk; 2) pemasaran produk di obyek wisata danau Rawa Pening, Bukit Cinta dan di ajang bazar dan expo tingkat propinsi; serta 3) pelaku usaha mampu membuat media sosial serta bergabung dalam dan mengisi konten dengan gambar produknya. Secara keseluruhan luaran dari pengabdian ini tercapai dan pelaku usaha memiliki komitmen untuk secara mandiri melakukan produksi, pemasaran, dan konsultasi dengan UNNES 


\section{PENDAHULUAN}

Keberadaan danau Rawapening yang ada di wilayah Kecamatan Tuntang, Ambarawa, Bawen dan Banyubiru kini makin kritis. Sekitar 60\%-70\% dari 2.770 hektare luas danau telah tertutup tanaman enceng gondok (Eichornia crassipes). Pertumbuhan eceng gondok yang sangat cepat ini dipengaruhi beberapa hal, salah satunya perubahan tingkat keasaman air (Yunus dkk, 2015) Selain kritis, kualitas danau semakin menurun dengan sedimentasi yang meninggi, sehingga jika tidak ditangani dengan baik, Rawapening diperkirakan menjadi daratan pada 2021 (Sriyanto, 2015).

Rawapening merupakan salah satu dari 15 danau di Indonesia yang harus diselamatkan. Pengelolaan Rawapening merupakan kewenangan Pemerintah Pusat, Pemerintah Provinsi dan Pemerintah Kabupaten Semarang yang melibatkan Dinas Pekerjaan Umum, Dinas Ciptakarya, Dinas Kebudayaan dan Pariwisata, Dinas Pertanian dan Dinas Lingkungan Hidup.

Bagi sebagian besar orang eceng gondok dianggap sebagai tanaman tidak berguna dan hanya menjadi penyebab terjadinya banjir karena selalu mengotori sungai. Namun bagi orang yang kreatif, eceng gondok dapat diolah menjadi berbagai barang kerajinan bernilai ekonomi tinggi bahkan telah menembus pasar ekspor.
Selain permasalahan sedimentasi Rawapening, permasalahan lain yang juga menjadi perhatian pemerintah pusat adalah jumlah pengangguran di Indonesia mencapai 10,6 juta jiwa (Bappenas, 2007). Tanpa adanya dukungan banyak pihak, pemerintah tidak mungkin sanggup mengatasi masalah ini dalam jangka waktu relatif singkat. Lembaga pendidikan tinggi mempunyai peran dan tanggungjawab yang besar dalam mencarikan solusi untuk mengatasi kondisi tersebut. Entrepreneuship (berwiraswasta/wirausaha) merupakan salah satu alternatif solusi tepat untuk mengatasi masalah pengangguran.

Desa Kebondowo dan Desa Demakan yang berada di Kecamatan Banyubiru yang berlokasi di dekat Rawapening memiliki sekelompok masyarakat yang belum memiliki pekerjaan atau bekerja serabutan. Meski demikian, di desa tersebut telah memiliki kelompok mitra yang memanfaatkan eceng gondok sebagai bahan baku produksi kerajinan tangan. Persoalan yang dihadapi oleh mitra dan perlu diperbaiki adalah masalah tenaga terampil membuat kerajinan eceng gondok masih sangat sedikit sehingga diperlukan pelatihan untuk menambah jumlah pengrajin sekaligus menumbuhkan wirausaha baru. Kemelimpahan eceng gondok sebagai bahan baku tetapi tidak didukung dengan sumberdaya manusia yang 
memadai dalam membuat kerajinan dan memasarkan produknya. Kelompok Mitra memiliki keinginan untuk menyelenggarakan pelatihan namun tidak memiliki biaya penyelenggaraan.

Menjawab permasalahan tersebut, pengelolaan eceng gondok yang terprogram, dapat diwujudkan dengan kampung kerajinan eceng gondok yang bisa menarik wisatawan. Program terencana harus diwujudkan agar potensi ekonomi eceng gondok yang dimanfaatkan dengan membuat kerajinan, pakan ternak, pupuk organik, media jamur merang, biogas dan perikanan dapat terangkat. Upaya fermentasi eceng gondok untuk pakan kambing dan akarnya dimanfaatkan untuk kompos, telah dimulai bersama-sama anggota Paguyuban Kampung Rawa. Paguyuban Kampung Rawa terbentuk dari 12 kelompok tani dan memiliki 316 anggota yang selama ini dibina oleh KSP Artha Prima menyatakan siap mengelola eceng gondok dan memberdayakan masyarakat mulai dari bidang ekonomi..

\section{METODE PEMECAHAN MASALAH}

Metode yang digunakan dalam melakukan pengabdian ini adalah:

1. Identifikasi masalah
Tim pengabdi melakukan pemetaan masalah mitra pengabdian dan penduduk sekitar yang perlu untuk diselesaikan. Termasuk di dalamnya mengidentifikasi jenis, kualitas, dan pemasaran produksi kerajinan tangan eceng gondok;

2. Analisis potensi

Analisis potensi dilakukan untuk mengetahui kondisi terkini dari mitra dan penduduk sekitar serta sumber daya yang dapat dimanfaatkan dalam pemanfaatan eceng gondok. Tahapan ini juga memetakan kelompok masyarakat mana yang layak latih dan memiliki komitmen untuk maju Bersama;

3. Pelatihan Teknologi pengolahan eceng gondok

Tahapan ini meliputi pemilihan eceng gondok yang berkualitas baik proses pra produksi (penjemuran/pengeringan);

4. Pelatihan pembuatan kerajinan tangan dari eceng gondok

Peserta pelatihan akan dilatih untuk membuat beberapa bentuk kerajinan eceng gondok terutama untuk kerajinan yang sudah banyak diperjualbelikan ataupun komoditi pesanan hotel di sekitar Salatiga.

5. Pelatihan e-commerce atau pemasaran online 
Pelatihan ini akan mengenalkan mitra kepada beberapa jalur pemasaran online baik melalui social media ataupun market place.

Kegiatan yang akan dilakukan diragkum pada table berikut:

Tabel 1. Program Kegiatan KKN di Desa Kebondowo

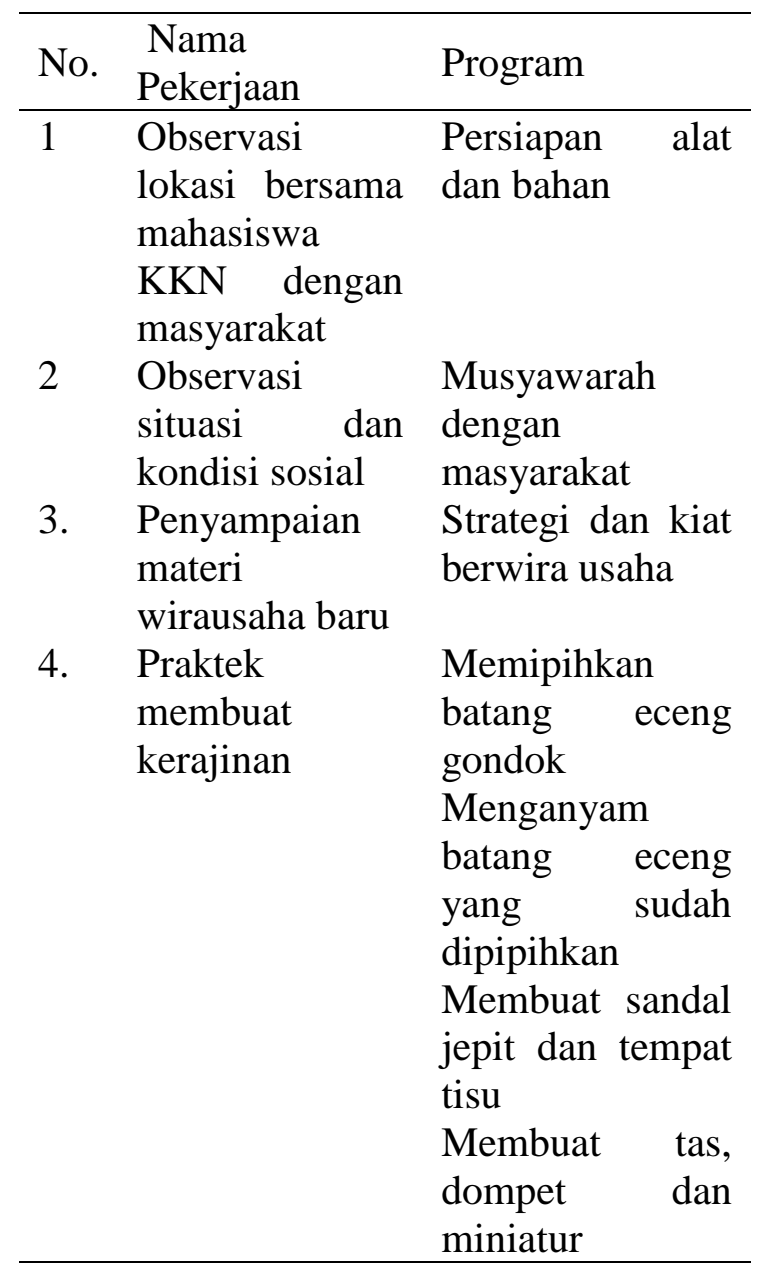

\section{HASIL}

Hasil yang didapatkan dari pelaksanaan pengabdian masyarakat adalah sebagai berikut:

1. Identifikasi masalah: Desa Kebondowo memiliki penduduk yang sebagian dan masyarakatnya masih bekerja serabutan atau pengangguran. Banyaknya eceng gondok serta permintaan dari hotel tidak sebanding dengan jumlah pengrajin. UMKM yang ada belum menerapkan manajemen usaha dan produksi yang berkaitan dengan aspek pasar, padahal aspek tersebut merupakan aspek pokok yang sangat penting dan menentukan keberhasilan dalam usaha dibidang kerajinan.

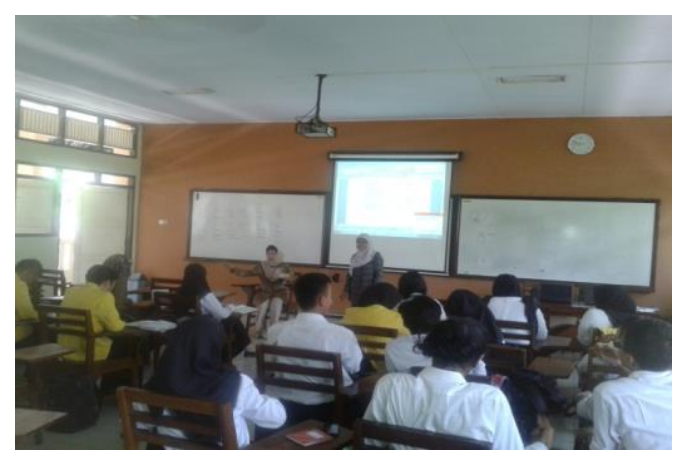

Gambar 1. Proses Identifikasi Masalah

2. Analisa potensi: bahan baku kerajinan eceng gondok sangat besar, selain itu sudah ada pengrajin dengan tingkat keterampilan mahir yang bias dijadikan tutor bagi pelatihan. Potensi pasar kerajinan yang ada Kampung Rawa cukup besar, dengan dukungan sarana prasarana daerah serta permintaan pasar dan dari berbagai daerah lain, baik dari Yogyakarta maupun Jawa Tengah, hal tersebut menunjukkan bahwa potensi pasar relatif cukup besar. 


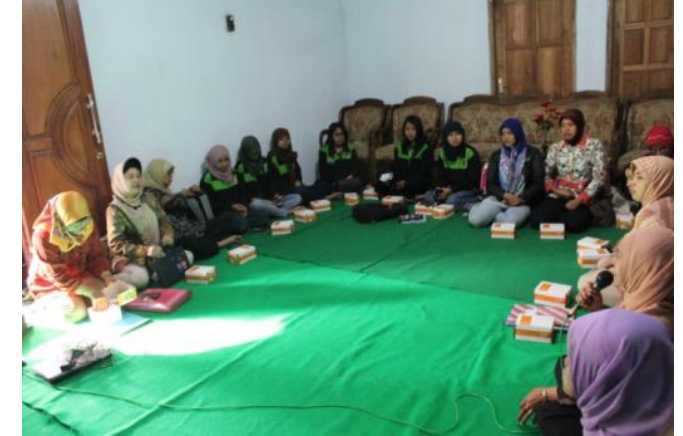

Gambar 2. Proses Pemetaan Potensi
3. Pelatihan Teknologi pengolahan eceng gondok: pelatihan yang dilakukan terkait dengan hal ini adalah pemilihan eceng gondok yang dapat menghasilkan serat yang baik serta tingkat kekeringan eceng gondok agar bisa dianyam dengan baik.

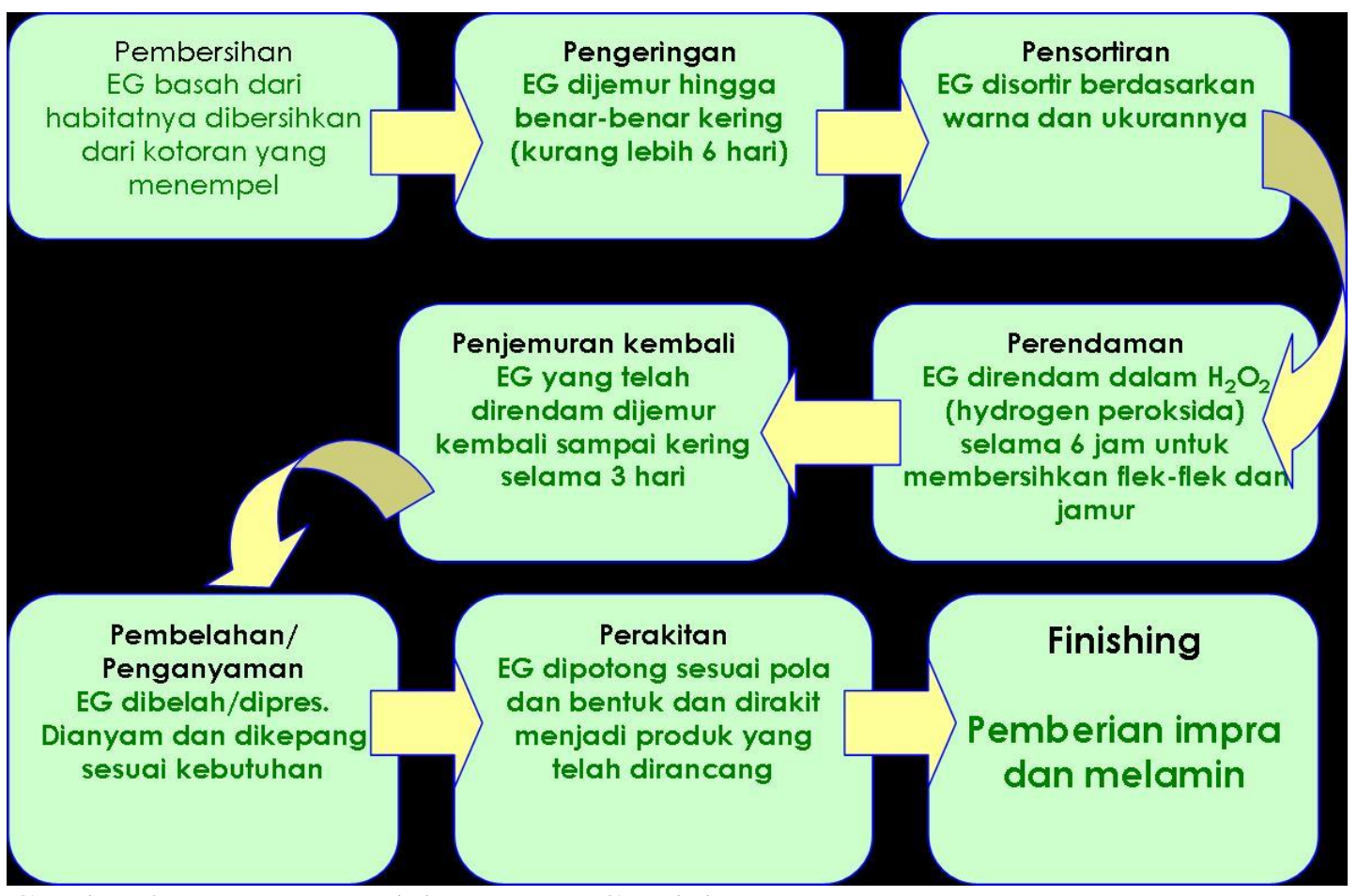

Gambar 3. Proses Pengolahan Eceng Gondok

4. Pelatihan pembuatan kerajinan eceng gondok: aspek yang diutamakan adalah aspek fungsi dan estetik (fashion). Aspek Fungsi yaitu kegunaan produk harus jelas, yang harus diperhatikan kekuatan, dan kenyamanan. Misalnya produk : tempat tisu, kaca rias. Aspek Estetik (fashion) adalah nilai seni yang ada pada produk. Setiap produk memiliki nilai estetikanya, mulai barang-barang sehari-hari yang sederhana sampai barang-barang yang dipergunakan untuk retise seseorang. Misalnya tempat pot, sandal, dompet dan tas. 


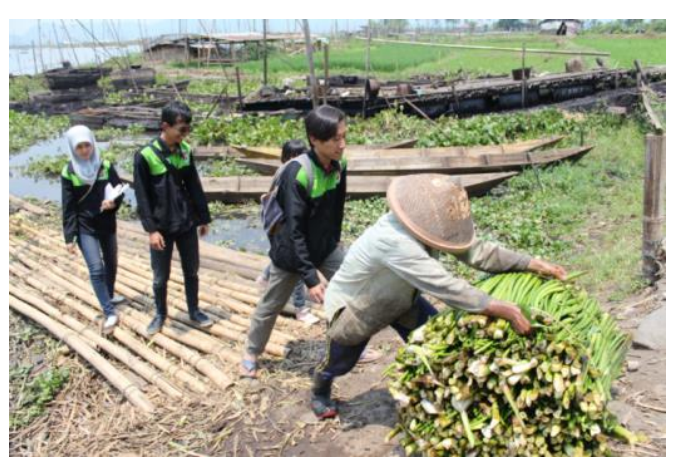

Gambar 4. Proses Pra Produksi

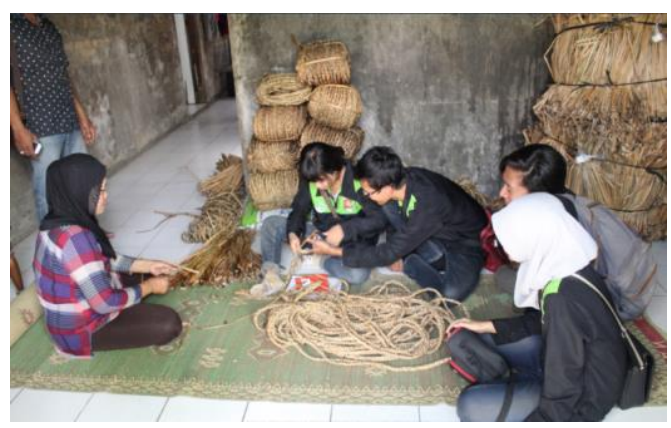

Gambar 5. Persiapan Pra Produksi

5. Pelatihan e-commerce, marketing dan branding: Pelaksanaan program kerja bidang ekonomi yaitu workshop marketing dan branding berjalan dengan lancar dibuktikan dengan antusiasme peserta PKK Desa Kebondowo yang tinggi dan banyaknya pertanyaan yang masuk terkait materi yang sampaikan. Materi dalam kegiatan ini yaitu tentang pemasaran berbasis online (E-commerce) dan branding. Materi tersebut berisi tentang bagaimana strategi pemasaran yang baik, fungsi dari pemasaran, dan juga konsep pemasaran itu sendiri. Kami juga memberikan beberapa contoh konkrit mengenai E-commerce tersebut sehingga materi lebih mudah untuk dipahami. Contoh pemasaran online yaitu pemanfaatan media social internet sebagai media pemasaran seperti Facebook, BBM, dan lain-lain yang sekarang sudah banyak digunakan kalangan masyakat.

\section{PEMBAHASAN}

Pemberdayaan masyarakat agar kegiatan dapat berlangsung secara berkelanjutan dengan cara diberi pelatihan pembuatan kerajinan eceng gondok melalui beberapa proses sederhana yaitu pertama, eceng gondok yang baru diambil dari sungai di jemur hingga kering, kemudian batang yang telah kering dibentuk lembaranlembaran kecil. Lembaran batang eceng gondok yang telah mengering inilah yang nantinya dianyam dan dibentuk menjadi kerajinan sesuai yang dikehendaki yaitu sepatu, sandal, dompet, tas, tempat tisu, miniatur, tempat sampah dan kotak file.

Pelatihan pembuatan kerajinan berbahan dasar eceng gondok sebagai produk sepatu, sandal, dompet, tas, tempat tisu, miniatur, tempat sampah dan kotak file. Untuk memperoleh hasil yang optimal tim KKN-PPM bekerjasama dengan Mitra Syarina Production Original Hand Made handicraft eceng gondok. Produk Syarina Production berbentuk miniatur mobil tanki, motor Harley Davidson, serta sepeda antik, bagus dan cukup halus. Jenis produk bisa dikategorikan menjadi 2, yaitu : 
- Produk Eksklusif : Produk yang dibuat karena adanya pesanan khusus atau dibuat khusus untuk seseorang pembeli ,dengan jumlah tidak banyak bisa dikatakan 1 desain 1 pembeli.

- Produk massal : Produk yang di desain untuk di produksi dalam jumlah banyak dan di konsumsi orang banyak.

Hasil kegiatan KKN PPM selama pelaksanaan di Desa Kebondowo Kecamatan Banyubiru Kabupaten Semarang adalah kegiatan dari program kerja utama dan program kerja pendamping.

Hasil kegiatan utama yang telah dicapai adalah bertambahnya tenaga terampil membuat kerajinan berbahan dasar eceng gondok yaitu 3 orang terampil membuat anyaman siap rangkai dari kelompok Rowoboni, 5 orang terampil membuat sandal dan lukisan bunga dari kelompok Demak'an, 5 orang terampil membuat vas bunga, tas wanita, tempat payung dan dompet kecil dari kelompok Sukodono, 2 orang terampil membuat miniatur kereta kuda dari kelompok Kesongo, 5 orang terampil membuat tempat tisue dan kaca hias dari kelompok Kebondowo.

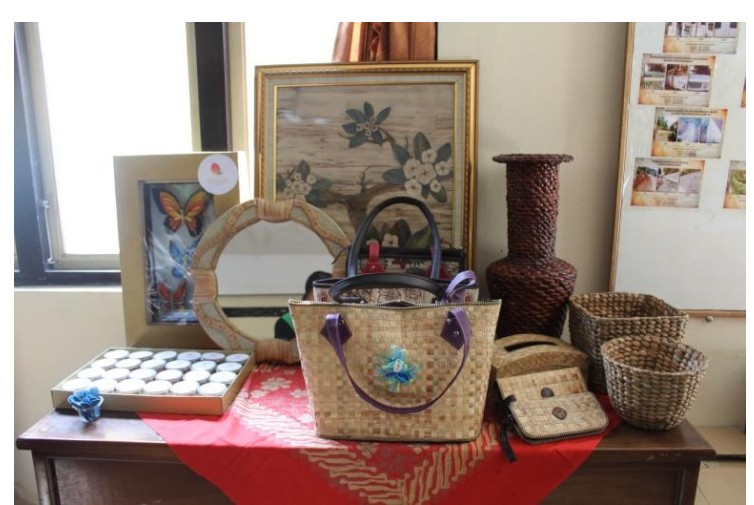

Gambar 6. Produk-produk kerajinan eceng gondok

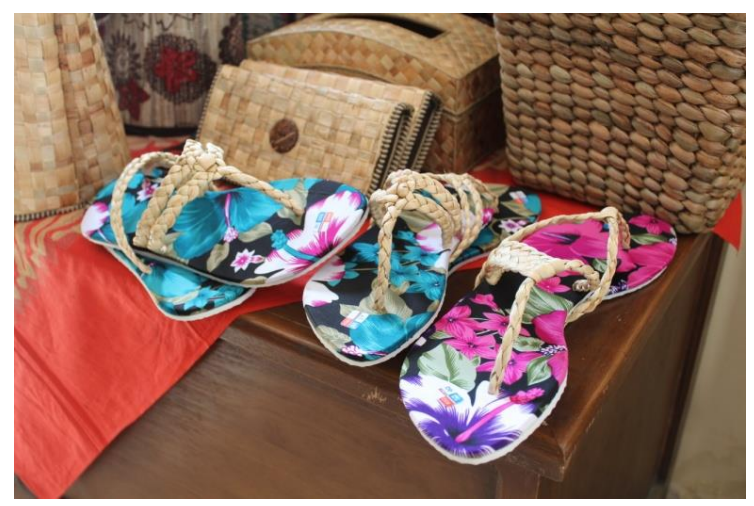

Gambar 7. Produk-produk kerajinan eceng gondok

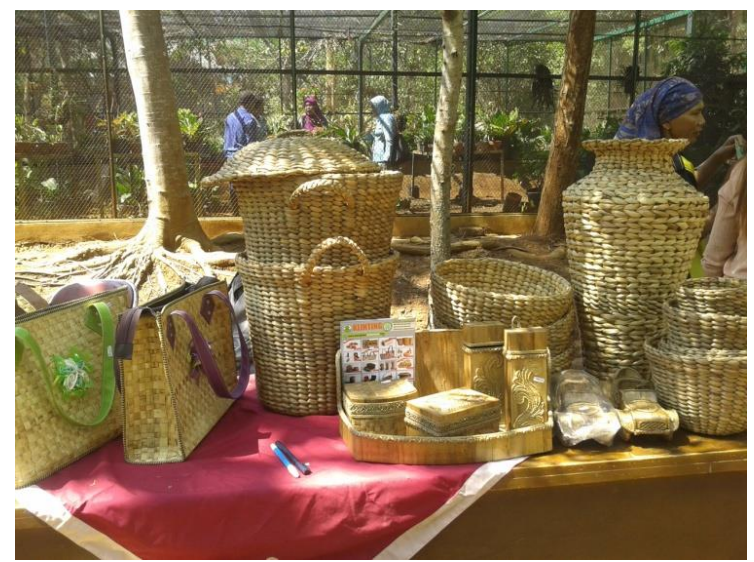

Gambar 8. Produk-produk kerajinan eceng gondok 


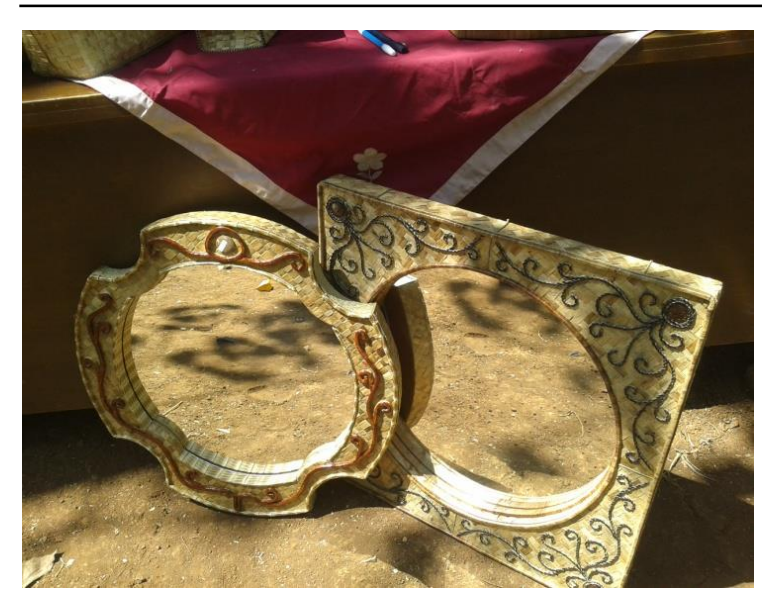

Gambar 9. Produk-produk kerajinan eceng gondok

Bertambahnya tenaga terampil sejumlah 15 orang maka dibentuk 5 kelompok wirausaha baru. Wirausaha baru yang terbentuk didampingi ketua dari tiap kelompok yaitu ketua kelompok Rowoboni, Demak'an, Sukodono, Kesongo dan Kebondowo. Modal awal masih dibantu oleh tim pengabdian kemudian dibuat berbagai produk, produk-produk tersebut dibeli sesuai kualitas, yaitu kerapian dan keindahan. Maksud dari perlakuan ini untuk menanamkan percaya diri bahwa produk yang dibuat sudah memenuhi standar kualitas sehingga layak jual. Diantara sejumlah produk ditemukan produk yang belum memenuhi standar jual, namun tetap dihargai walau dengan harga rendah. Dalam hal ini tim pengabdian memberi motivasi kepada wirausahabaru untuk tetap menjaga kualitas produk untuk layak jual.

\section{Pelatihan pembuatan kerajinan eceng gondok}

Program ini adalah program utama dari serangkaian kegiatan KKN-PPM Unnes, di Desa Kebondowo Kecamatan Banyubiru Ambarawa Semarang. Kegiatan pelatihan ini merupakan program pengabdian masyarakat yang dilaksanakan oleh mahasiswa di bawah program pengabdian dosen UNNES. Waktu pelaksanaan kegiatan ini adalah 3 kali dalam satu bulan yaitu setiap hari kamis pada minggu ke-3 s/d ke-5 selama KKN. Kegiatan ini dilaksanakan mulai pukul 09.00 WIB hingga selesai. Tempat pelaksanaan terdapat pada 7 cluster. Relevansi kegiatan ini merupakan kegiatan pengabdian kepada masyarakat yang dilaksanakan sebagai program utama dalam serangkaian kegiatan KKN-PPM UNNES.

Hambatan-hambatan dalam kegiatan ini adalah kurangnya waktu yang intensif untuk membuat kerajinan, minim modal dan kurangnya inovasi dari produk yang dihasilkan. Usaha mengatasi hal tersebut adalah dengan memberikan sosialisasi dan pelatihan, pendekatan masyarakat akan pentingnya berkreasi dan berwirausaha, pendampingan per cluster dan pelatihan "Marketing and Branding" sebagai upaya lanjutan untuk memaksimalkan income pengrajin dan kualitas produk. Hasil-hasil yang dicapai dari program pelatihan ini adalah masyarakat desa Kebondowo memiliki tingkat kreativitas yang cukup 
baik, inovasi produk yang beraneka ragam, meningkatnya kesadaran dan pentinya berwirausaha serta masyarakat mengetahui pentingnya branding untuk memaksimalkan kualitas produk mereka agar memiliki nilai jual yang meningkat baik pasar di dalam maupun diluar negeri.

Respon masyarakat dengan pelatihan kerajinan eceng gondok sangat antusias karena produk yang dibuat sudah layak jual sehingga semangat berinovasi terus diupayakan. Sebagai pengalaman untuk kelompok sukodono diajak untuk mengikuti pameran pada kegiatan expo laboratorium biologi dan peluncuran oemah keboen. Tujuan kegiatan pameran adalah untuk mengetahui sejauh mana produk eceng gondok diminati oleh masyarakat, sekaligus mengenalkan produk berbahan dasar eceng gondok adalah tanaman yang sebetulnya sangan merugikan kualitas perairan di Rawa Pening. Hasil kegiatan ini ada beberapa pesana pot bunga, sandal dan tas wanita.

Pelaksanaan kegiatan pelatihan dilakukan di tiga Cluster yang terdapat menyebar di wilayah Kebondowo Timur. Pelaksanaan kegiatan ini adalah di 7 cluster. Berikut merupakan nama cluster beserta produk unggulan:

1) Aiboni, produk unggulan anyaman sebagai bahan dasar pembuatan dompet dan tas.
2) Renita, produk unggulan yaitu tas, dompet, lukisan, dan sandal

3) Ibu Komirah belum ada namanya, produk unggulan tas, box, pot bunga, tempat sampah dan wadah tisu

4) Mas Kuat, produk unggulan berupa tas

5) Production, produk unggulan berupa dompet

6) Pak Riamanto, produk unggulan berupa miniatur benda

7) Pak Budiman, produk unggulan berupa mebel enceng gondok

Sasaran pelatihan eceng gondok ini adalah remaja karang taruna, ibu rumah tangga, dan masyarakat desa kebondowo pada umumnya. Pentingnya kegiatan pelatihan eceng gondok ini adalah bagi sebagian besar orang eceng gondok dianggap sebagai tanaman tidak berguna dan hanya menjadi penyebab terjadinya banjir karena selalu mengotori sungai dan rawa. Namun bagi orang yang kreatif, eceng gondok dapat diolah menjadi berbagai barang kerajinan bernilai ekonomi tinggi bahkan telah menembus pasar ekspor. Pemberdayaan masyarakat supaya kegiatan dapat berlangsung secara berkelanjutan dengan cara diberi pelatihan pembuatan kerajinan eceng gondok. 


\section{Workshop Branding dan Marketing}

Kegiatan ini dilaksanakan pada 3 Oktober 2015 pukul 13.00 s/d 16.00 WIB bertempat di Balai Desa Kebondowo. Sasaran dari program ini yaitu ibu-ibu PKK se-Desa Kebondowo. Kegiatan ini dihadiri kurang lebih 50 peserta ibu ibu PKK Desa Kebondowo. Materi yang telah disampaikan bermanfaat untuk menambah wawasan masyarakat dalam memanfaatkan internet untuk mengembangkan usaha dan memperluas jaringan pasar produk dari masyarakat.

Kendala dalam melaksanakan kegiatan ini antara lain yaitu keterbatasan tempat atau ruang peserta workshop marketing dan branding. Hal ini terjadi karena aula Balai Desa Kebondowo memiliki ukuran yang tidak terlalu besar. Akibatnya panitia tim KKN PPM UNNES 2015 harus mengatur konsep ruang sebaik mungkin.

\section{KESIMPULAN}

Hasil kegiatan yang utama adalah bertambahnya tenaga terampil membuat kerajinan berbahan dasar eceng gondok. Selain itu, lingkup pemasaran juga semakin luas terbukti dari adanya pesanan kerajinan eceng gondok tidak hanya dari dalam kota saja tetapi dari luar kota.

\section{SARAN}

Untuk menyelesaikan kegiatan utama yaitu menumbuhkan wirausaha baru di bidang kerajinan eceng gondok dalam mencapai tujuan masih diperlukan perencanaan dan pengelolaan secara terkendali berkaitan dengan ketersediaan waktu. Keberlanjutan kegiatan utama adalah membuat perencanaan berdasarkan penemuan masalah saat pelaksanaan sekarang yang dapat digunakan untuk kemungkinan pencapaian kegiatan berikutnya. Contohnya permasalahan pengelolaan daun eceng gondok menjadi produk diversifikasi secara komersial.

\section{DAFTAR PUSTAKA}

Nata, I. F., Niawati, H., \& Muizliana, C. (2013). Pemanfaatan serat selulosa eceng gondok (Eichhornia Crassipes) sebagai bahan baku pembuatan kertas: isolasi dan karakterisasi. Konversi, 2(2), 9-16.

Pasaribu, G. (2008). Pengolahan Eceng Gondok Sebagai Bahan Baku Kertas Seni. Makalah Utama Pada Eksposs Hasil-hasil Penelitian : Konservasi dan Rehabilitasi Sumberdaya Hutan, Padang.

Setyanto, K. (2011). PEMANFAATAN ECENG GONDOK UNTUK MEMBERSIHKAN KUALITAS 


\section{AIR SUNGAI SUNGAI \\ GADJAHWONG}

YOGYAKARTA. Jurnal Teknologi

Technoscientia, 17-22.

Sittadewi, E. H. (2011). Pengolahan Bahan

Organik Eceng Gondok Menjadi

Media Tumbuh untuk Mendukung

Pertanian Organik. Jurnal Teknologi

Lingkungan, 8(3).

Yunus, R., Priatmadi, B. J., Leksono, A. S., \& Kusuma, Z. Effect of $\mathrm{pH}$ changes on the growth of water hyacinth (Eichhornia crassipes (Mart.) Solms.) in acid mine drainage. Journal of Biodiversity and Environmental Sciences (JBES). 